Яцій, Василь. «До походження давніх топонімів Львівської області (матеріали до історикоетимологічного словника). 35-41». Лінгвостилістичні студіï, вип. 13, 2020, с. 186-98.

Yatsiy, Vasyl. "On the Origin of the Old Toponyms of the Lviv Region (Materials for the Historical-Etymological Dictionary) 35-41". Linguostylistic Studies, iss. 13, 2020, pp. 186-98.

УдК 811.161.2'373.21

https://doi.org/10.29038/2413-0923-2020-13-186-198

\title{
ДО ПОХОДЖЕННЯ ДАВНІХ ТОПОНІМІВ ЛЬВІВСЬКОЇ ОБЛАСТІ (МАТЕРІАЛИ ДО ІСТОРИКО-ЕТИМОЛОГІЧНОГО СЛОВНИКА). 35-411
}

\author{
Василь Яцій \\ Інститут української мови НАН України, \\ Київ, Україна
}

\begin{abstract}
1 Продовження циклу статей, опублікованих у: Студії з ономастики та етимології. 2010, відп. ред. I. В. Сфименко. Луцьк: Терен, 2010, с. 274-285 (Артасів, Буча́ли, Викоти, Глиняни, Голобутів, Грі́мне, Доброси́н, Жви́рка, Ка́вське, Корчи́н, Лю́бша); Вісник Прикарпатського національного університету імені Василя Стефаника. Серія: Філологія, ред. колегія: В. Г. Матвіїшин (голова), Д. Г. Бучко, М. І. Голянич, В. В. Грещук, В. І. Кононенко та ін. Івано-Франківськ: Видавництво Прикарпатського національного університету, вип. XXIX-XXXI, 2011, с. 131-133 (Ко́лтів, Поте́лич, Рода́тичі, Судо́ва Ви́шня); Життя - у слові: збірник наукових праць на пошану академіка В. М. Русанівського, відп. ред. В. Г. Скляренко. Київ: Видавничий дім Дмитра Бураго, 2011, с. 146-151 (Бари́лів, Більче, Винники, Доброго́стів, Корничі, Ма́лнів); Актуальні проблеми філології та перекладознавства: збірник наукових праць, гол. ред. М. С. Скиба; відпов. за випуск М. М. Торчинський. Хмельницький: Хмельницький державний центр науки, інновацій та інформатизації, вип. 6, Ч. 2, 2013, с. 288-294 (Опільсько, Отине́вичі, Пиратин, Хо́дорів, Чолгині, Чуперносів, Шни́рів); Записки з ономастики = Opera in опотаstica: збірник наукових праць, ред. колегія: О. Ю. Карпенко (відп. ред.), Т. Ю. Ковалевська, Е. В. Боєва, О. І. Бондар, В. О. Горпинич та ін. Одеса: Астропринт, вип. $18=$ Fascicullum 18, 2015, c. 838-846 (Артищів, Ба́личі, Бачів, Буськ, Дроговиж, Пони́ква). Див. ще шість статей, які присвячені цій же проблематиці: «Матеріали до історико-етимологічного словника ойконімів Львівщини». Студї з ономастики та етимології. 2011-2012, відп. ред. О. П. Карпенко, В. П. Шульгач. Київ: Кий, 2012, с. 257-265 (Андріївка, Арла́мівська Во́ля, Ба́ківці, Велика Озимина, Гі́йче, Гнізди́чів, Діди́лів, Дуна́їв, Зава́дів, Заплатин, Ку́пновичі, Лю́биниі); «Про походження ойконіма Белз». Праџі Центру пам'яткознавства: збірник наукових праџь, гол. редколегії О. М. Титова. Київ: Центр пам'яткознавства НАН України і УТОПІК, виП. 21, 2012, с. 217-222 (Белз); «Топонімія Радехівського району Львівської області (матеріали до історикоетимологічного словника ойконімів України). І». Студії з ономастики та етимології. 2013, відп. ред. О. П. Карпенко, В. П. Шульгач. Київ: Кий, 2013, с. 206-221 (Ада́мі́вка, Андріївка, Бабичі, Бари́лів, Батиїв, Бебехи, Березівка, Би́шів, Волиця, Волиця-Барилова, Вузлове́, Гоголів, Грицеволя, Гута-Скляна, Дми́трів, Дубини, Заба́ва, Завидче, Загатка, Збоївська, Йосипівка, Корчи́н, Корчівка, Криве, Куликів, Ку́стин, Кути, Лопа́тин, Микола́їв, Монастирок-Огля́дівський, Мукані, Неми́лів, Нестаничі, Ни́виці, Нови́й Ви́тків, Новоставичі, Обортів, Огля́diв, Оплічько, Ордів); «Топонімія Радехівського району Львівської області (матеріали до історико-етимологічного словника ойконімів України). ІІ». Студії з ономастики та етимології. 2014, відп. ред. В. П. Шульгач. Київ: Кий, 2014, с. 120-133 (Па́влів, Пиратин, Підмонастирок, Поздимир, Полове́, Пустельники, Радваниі, Раде́хів, Раковище, Розжалів, Романівка, Руденко, Сабанівка, Середпі́льці, Синьків, Смо́ржів, Станин, Старий Майдан, Стирківці, Стоя́нів, Стремільче, Су́шно, Тете́вчиці, Тоболів, Торки, Трійия, Увин, Хмільно, Шайноги, Щуровичі, Я́струбичі); «Топонімія Сколівського району Львівської області (матеріали до історико-етимологічного словника ойконімів України). І». Студї з ономастики та етимології. 2015-2016, відп. ред. О. П. Карпенко. Київ: Видавництво ТОВ «КММ», 2017, с. 186-198 (Ве́рхнє Синьови́дне, Ве́рхня Рожанка, Верхня́чка, Волося́нка, Голове́иько, Грабовець, Гребенів, До́вжки, Долинівка, Дубина, Жупа́ни, За́ва́дка, Задільське, Зимівки, Кальне, Кам'янка, Климе́иь, Козьова́, Коро́стів, Ко́рчин, Криве, Крушельниця, Ла́вочне, Либохора, Межиброди, Мита, Нагірне, Ни́жнє Синьови́дне, Ни́жня Рожанка); «Топонімія Сколівського району Львівської області (матеріали до історико-етимологічного словника ойконімів України). ІІ». Студії з ономастики та етимології. 2017-2018, відп. ред. В. П. Шульгач. Київ: [б. в.], 2018, c. 187-199 (Опоре́uь, О́рів, Оря́ва, Орявчик, Підгородиі, Пла́в’я, Побук, Погар, Пшонеиь, Риків, Росоха́ч, Ско́ле, Славське, Смо́же, Сопіт, Сухий Потік, Тернавка, Тисовеиь, Тишівниця, Труха́нів, Ту́хля, Ту́холька, Урич, Хашованя, Хітар, Ялинкувате, Яме́льниия).
\end{abstract}

(C) Яцій В., Волинський національний університет імені Лесі Українки, 2020.

Це стаття відкритого доступу на умовах CC BY-NC 4.0 
Стаття присвячена лінгвістичному аналізу сучасних назв населених пунктів Львівської області: Бі́брка¹, Бі́тля, Бо́риня, Вели́ке Коло́дно, Верхня Лукавиця, Городисько та Демня. На матеріалі документально засвідчених історичних фіксацій найдавніших ойконімів досліджуваного регіону України простежено як особливості словотвірних моделей, так і фонетичні модифікації аналізованих онімів у часі.

Ключові слова: антропонім, особова назва, патронім, апелятив, ойконім, онімізація.

\title{
ON THE ORIGIN OF THE OLD TOPONYMS OF THE LVIV REGION (MATERIALS FOR THE HISTORICAL-ETYMOLOGICAL DICTIONARY) 35-41
}

\author{
Vasyl Yatsiy \\ Institute of the Ukrainian Language of National Academy of Sciences of Ukraine, Kyiv, Ukraine
}

The article is devoted to the linguistic analysis of the settlements' names of Lviv region: Bibrka, Bitlia, Borynia, Velyke Kholodno, Verkhnia Lukavytsia, Horodysko, and Demnia, which differ from other oikonyms of this region by their chronological and derivational features. The non-slavic proprietary materials were used to explain some names. The article presents brief etymology descriptions of the described in the article Lviv toponyms.

Oikonym Bíbrka (fixed at the beginning of the $13^{\text {th }}$ century) is motivated by the corresponding microtoponym, which, in turn, is genetically reduced to the Proto-Slavic *bobrzkъ (beaver).

The name of the village of Bítlya (known from the middle of the $16^{\text {th }}$ century), which over time changed from Butlya, we relate to the Ukrainian dialect adjective býtlyavy 'empty', 'rotten inside' verb býtliti, butliet 'to rot'.

Oikonym Borynia (mentioned in the historical sources of the middle $16^{\text {th }}$ century) most likely, originated from the local similar hydronym Borynia (basin of Dniester). But, etymologizing these onyms, the researchers suggest the opposite process, that is, oikonym $\rightarrow$ hydronym.

Oikonym Velyke Kholodno (documented at the end of the $14^{\text {th }}$ century) is motivated by an identical adjective. Compare, for example, Old Russian kholodny, which refers to a deck, and Old Ukrainian kolodnyi in the phrase zeml \# kolodnaya (a piece of land in the forest with logs (hemp), set aside for breeding bees).

We consider the oikonym Verkhnia Lukavitsa (known since the end of the $18^{\text {th }}$ century) as a derivative, which is motivated by the local (micro) toponym $\operatorname{Luka}(o)$ viy $(-a,-e)+$ formant - $t s a$, and that, in its turn, occured as a result of onimization of the corresponding appellatives, which denoted curvature, bends (of rivers, streams, streams, etc.).

Oikonym Horodysko (documented in 1569 as Hrodzysko) we qualify as a derivative of the geographical appellative horodysko/городисько.

Oikonym Demnia (recorded in written historical monuments since 1453) researchers etymologize in different ways: a) the settlement used to be constantly in smoke (Ukrainian "zadimlene"); b) the name is motivated by the word domnytsia (furnace for smelting iron from swamp ore); c) most likely came from the appellative demnia (chimney (in the smithy).

Thus, both the features of the word-formation models and phonetic modifications of the analyzed onyms in time have been traced on the materials of the documented historical fixations of the oldest oikonyms of the Lviv region. onimization.

Key words: anthroponym, personal name, patronym, appellative, oikonym,

\footnotetext{
${ }^{1}$ Місце наголошування в ойконімах подано за «Історією міст і сіл Української РСР: Львівська область» (див.: Список використаних джерел).
} 
Вступ. Актуальність в аналізі ойконімікону окремих назв населених пунктів того чи того адміністративно-територіального району України полягає насамперед у тому, що таке дослідження вимагає більш комплексного підходу до поставленої проблеми та визначається інформаційною глибиною фіксацій онімів у діахронічній площині. У середовищі ономастів ойконіми становлять більш популярний об'єкт для дослідження, порівняно, наприклад, із мікротопонімами. Це, мабуть, пов'язано з тим, що назви населених пунктів генетично більш близькі для жителів будь-якого поселення з погляду зацікавлення до походження, історії. Цінність найменувань населених пунктів нині помітно зростає насамперед як об'єкта ономастично-етимологічних досліджень, завдяки яким можемо не тільки здійснити історично-лінгвістичний аналіз певного ойконіма, а й крізь призму таких досліджень побачити процес формування поселення й відповідно його назви.

Ойконімія Галичини в цілому і сучасної Львівської області зокрема давно стала об'єктом ретельних і скрупульозних досліджень вітчизняних та закордонних (здебільшого польських) учених, а саме: $Є$. М. Черняхівської,

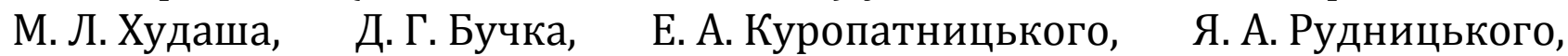
М. О. Демчук, М. Долинської, В.В.Грабовецького, В. П. Лаби, В.В.Котович, О. А. Купчинського, Я. П. Редькви, І. К. Свєшнікова, А. Чаплі та ін.

Львівська область, назви поселень якої стали об'єктом наших студій, розташована в західній частині України й утворена 4 грудня 1939 року. На теренах області археологи знайшли численні історичні пам'ятки, що свідчить про раннє заселення цього регіону. Перші сліди перебування людини на території області сягають доби палеоліту. Багато археологічних знахідок виявлено поблизу таких населених пунктів Львівщини, як: с. Баличі (Мостиський р-н), м. Буськ (Буський р-н), с. Велика Озимина (Самбірський р-н), м. Винники (Львівський р-н), с. Затока (Яворівський рн), м. Са́мбі́p (Самбірський р-н), с. Чи́шки (Пустомитівський р-н) та ін. Докладніше про давність заселення території області див. ще: (Історія 10, $11,52,171,494,605,640,683,925)$.

Мета дослідження. Мета пропонованої розвідки - історикоетимологічний аналіз назв поселень Львівської області: Бі́брка, Бі́тля, Бо́риня, Вели́ке Коло́дно, Верхня Лукавищя, Городисько та Демня, історія яких сягає у глибоку давнину XII-XIV ст.

Матеріал і методи дослідження. Специфіка об'єкта і поставлені в статті завдання зумовили використання різноманітних методів. У нашій роботі основними методами дослідження стали: ареальний для виокремлення та обмеження дослідження окремої адміністративної одиниці України; внутрішньої реконструкції з елементами етимологічного аналізу для відтворення праформ онімів Львівщини. Використано й порівняльно-історичний метод для зіставлення отриманих результатів із аналогічними даними інших сусідніх областей та країн. 
Джерельну базу для дослідження почерпнуто 3 територіальних довідників, краєзнавчих енциклопедій, різноманітних географічних, діалектних, тлумачних словників та інших історичних джерел, зокрема, довідника «Українська РСР: Адміністративно-територіальний устрій на 1 січня 1987 р.», енциклопедії «Історія міст і сіл Української РСР: Львівська область»; словників: "Słownik geograficzny Królestwa Polskiego i innych krajów słowiańskich", "Russisches geographisches Namenbuch"; історичних праць: «Архив Юго-Западной России, изд. Временною комиссиею для разбора древних актов», «Йосифінська (1785-1788) і Францисканська (1819-1820) метрики. Перші поземельні кадастри Галичини. Покажчик населених пунктів», які відображають ойконімію сьогодення і містять чимало історичних та археологічних відомостей про населені пункти, зокрема про час та умови їх заснування.

Результати дослідження та дискусія. Бі́брка - місто Перемишлянського р-ну. Із такою назвою населений пункт відомий, згідно 3 даними писемних джерел, від 1211 р. (Історія 551). У наступні роки поселення фігурувало під назвами: у 1433 p. - Bobrka (цит. за: Котович «Походження назв населених пунктів Опілля» 14), у 1497 р. - Novobobrka (після надання Бобриі магдебурзького права в 1469 р. міський центр поступово переходить на висілок, який починає іменуватися як Новобобрка. У XVI ст. Новобобрка називається Бобркою, а первісне поселення - Лани Малі або Стара Бобрка) (цит. за: Котович «Походження назв населених пунктів Опілля» 14); у 1564 р. - "Lani Małe albo Stara Bobrka", у XVI ст. - (Бобрка) (цит. за: Котович «Походження назв населених пунктів Опілля» 14); у 1553 р. - «домагань <...> (Бібрки)» (цит. за: Лаба, «Історія села Жирівка» 6); у 1758-1765 pp. - "in decanatu Bobrecensi", "in oppido Bóbrka", "comendarius Bobrecensis", "capitaneatum Bobrecensem", "oppido Bobrka" (Архив I/4: 532, 533); у 1785-1788 pp. та 1819-1820 pp. «Бібрка (Вóbrka)» (Йосифінська 31); у 1880 p. - "od Bóbrki" (Słownik geograficzny I: 85); у 1946 р. - Бобрка (Українська 323); у 2005 р. - «у місті Бібрці» (цит. за: Лаба, «Історія села Ліщин» 5). Ойконім мотивований суміжним мікротопонімом (назвою урочища) і гідронімом Боберка ${ }^{1}$ (пор., наприклад: «на рһкоу Бобръкоу», 1211 p. (Етимологічний словник літописних 20)) - ріка (л. Дністра (Історія 551)) історично - Бобръка, які дослідники розглядають у зв'язку 3 первісним *bobrъkъ 'бобер' 3 подальшою зміною граматичної форми чол. роду на жін. рід у результаті узгодження з лексемою річка. Більше разом із іншими версіями пояснення гідроніма див. у: (Вербич 93-94). Щодо споріднених місцевих назв пор. ще pp. Бібрка (Bóbrka) п.Сяну в бас. Вісли (в межах України тече тільки в Турківськ. р-ні) (Словник гідронімів 52), Бобрка в бас. Південного Бугу (Масенко 14).

\footnotetext{
1 За даними «Історії міст і сіл Української РСР: Львівська область», гідронім Боберка (Бобрка) постав тому, що тут здавна водилося багато бобрів. Про це докладніше див.: (Iсторія 551).
} 
Варіанти ойконіма Новобобрка і Стара Бобрка пов'язані з сусіднім нп Бобрка. Компоненти Ново- й Стара слугували, швидше за все, для розрізнення.

Інший історичний варіант назви поселення - Лани Малі - результат онімізації словосполучення лани малі.

Бі́тля - село Турківського р-ну. Найменування населеного пункту історично засвідчене в документах від 1565 р. (Історія 877). У 17851788 pp. та 1819-1820 pp. розглядуване поселення фігурує 3 назвою «Бітля (Butla)» (Йосифінська 34), у 1946 р. незмінно - Бітля (Українська 135). Сучасна словоформа Бітля видозмінена з Бутля. Дослідники етимологізують ойконім Бутля у колі слов'янської лексики, наприклад: укр. діал. бу́тлявий 'пустий', 'згнилий усередині', слвц. butly, butl'avý 'трухлявий', що пов'язані з дієсловами бу́тліти, butliet' 'гнити' (Słownik prasłowiański I: 455), пор. ще блр. бутлы 'трухлявий' (Слоўнік 1: 217) 'гнилий', болг. бутел 'про гнилий плід' (Шульгач, «Основа» 93), укр. бу́тіль 'гниль' (Етимологічний словник української 1: 309) < буте(о)ль < псл. *butlь. Пояснюючи гідронім (ойконім) Бутля у генетичному зв'язку з номенами зі семантикою гнилизни, затхлості, вчені влучно відзначають важливу позамовну особливість: поселення Бутля розташоване над р.Гнила (Вербич 54-55; із покликанням на: Słownik geograficzny II: 484).

Бо́риня - селище міського типу Турківського р-ну. Давнє поселення, неподалік якого розкопано історичні пам'ятки черняхівської культури IIIV ст. (Історія 11, 868). Назва селища документально фігурує на сторінках історичних документів від 1552 р. (Історія 868). Пізніші їі фіксації: «Бориня (Borynia)», 1785-1788 pp. i 1819-1820 pp. (Йосифінська 38); "od Boryni", 1881 p., "w Boryni", 1883 p., 1885 p., 1895 p. (Słownik geograficzny II: 104; IV: 766; VI: 845; XIV: 255); Бориня, 1946 р. (Українська 135); «села <...> Бориню», 1993 р. (Подорожі 15). Розглядуваний ойконім пояснюють як: 1) в основі топоніма Бориня - апелятив бор 'бір - сосновий ліс' (Рудницький 43; Лучик 60); 2) дериват від первісного *borynь < *borъ (Шульгач, «К реконструкции» $71)^{1}$; 3) онімне утворення від основи *bor- <*boriti (sę) ‘боротися’ (Козлова 29), пор. ще віддієслівне ім'я *borъ 'боротьба' (Słownik prasłowiański I: 336); 4) на наш погляд, це насамперед результат трансонімізації місцевого гідроніма Бори́ня (бас. Дністра) - назва ріки (Словник гідронімів 64). Водночас вірогідний і зворотній процес онімотворення, тобто ойконім $\rightarrow$ гідронім. Розглядаючи й аргументуючи обидва варіанти утворення місцевої назви Бориня як альтернативні, С.О.Вербич аргументовано зазначає, що: а) за первинності назви водного об'єкта, гідронім Бориня *'річка, що переборює перешкоди' (тобто тече у важкодоступній місцевості, адже Бориня - це гірська річка, яка витікає з Бескидського узгір'я (Вербич 266, із покликанням на: Słownik geograficzny I: 332)): *borynь

\footnotetext{
${ }^{1}$ Цю версію спростовує С. О. Вербич, на думку якого, зв’язок праформи *borynь із *borъ малоймовірний, оскільки в діалектах української та інших слов'янських мов на позначення реалії 'сосновий ліс' функціонує лексема борина « *borina, як і типологічно споріднені *dobina, *grabina. Докладніше про це див.: (Вербич 266).
} 
( *borъ 'боротьба'; б) якщо ж первинний ойконім, то, на переконання вченого, він мотивований антропонімом Боринь \& *borynь 'той, хто бореться' < *borъ 'боротьба'. Про це більше див.: (Вербич 266). Сюди ж додамо ще аналогічні ойконіми в інших слов'янських регіонах: рос. Борыня на Новгородщині (Russisches I: 515), Борыни, Борыня, (похідне) Борынско (Новгородские III: 68; IV: 310; Шульгач, «К реконструкции» 71), пол. Borynia (3 фіксації) - топоніми, Borynia Dolna, Borynia Górna - мікротопоніми в Сілезії (Nazwy geograficzne 1: 87); а також гідроніми: (відтопонімне похідне на -ськ-ий) Бори́нський - назва потоку в бас. Тиси (Словник гідронімів 64), пол. Borynie / Boryń у басейні Вісли (Hydronimia 249) і под.

Вели́ке Коло́дно - село Кам'янка-Бузького р-ну. Уперше назва села задокументована в 1389 р. (Історія 436); згодом ойконім згадується в писемних пам'ятках як: «Колодно (Kłodno Wielkie)», 1785-1788 pp. i 18191820 pp. (Йосифінська 150); “Kłodno (wielkie, po rusku Kołodno)", 1883 p. (Słownik geograficzny IV: 185); Колодно Велике (до 1946 р.) (Українська 886); Велике Колодне, 1946 р. (Українська 334); «між <...> Колодним і Колоденцем», 1968 р. (Історія 417); Велике Колодно, 2012 р. (Україна 220). Складена назва, стрижневий компонент якої - Колодно / Колодне розглядаємо як онімізацію ідентичного прикметника колодний, який має інослов'янські аналоги, як-от: д.-руськ. колодный 'який стосується колоди' (Этимологический 10: 127), ст.-укр. колодныи, у словосполученні зємл\# колодная 'ділянка землі в лісі з колодами (пнями), відведена на розведення бджіл' (Словник староукраїнської I: 395), блр. діал. кало́дны 'вулик (із колоди)', ст.-пол. kłodny 'колодний', 'в'язничний' і под. > псл. *koldьnъ(jb) (Этимологический 10: 127). Означення Велике функціонує, швидше за все, для розрізнення зі спільнокореневими ойконімами в цій же області, наприклад: Колоденці цього ж району, Колодниця у Стрийському р-ні (Україна 220, 228). Пор. ще ойконім ст.-укр. Колодэн - назва міста в історичній Волинській землі (Словник староукраїнської I: 490), Кла̀дањ, Кла̂дањ - топоніми в Боснії (Этимологический 10: 127); додамо також, що в Україні відомо ще три однойменні водні об'єкти (Словник гідронімів 263).

Верхня Лукавиця - село у Стрийському р-ні. Об’єднане з нп Долі́шнє (Україна 228). Ойконім відомий у 1785-1788 рр. та 1819-1820 рр. як «Лукавиця Вижня (Łukawica Wyżna)» (Йосифінська 182); до 1946 р. - як Луковиця Горішня (Українська 888); у 1946 р. та 1968 р. - як Верхня Луковищя (Українська 149; Iсторія 833). Складена назва, в якій стрижневий компонент Лука(о)виця розглядаємо як дериват від імовірного (суміжного) (мікро)топоніма Лука (о)вий $(-a,-e)$ (земля, садиба, оселя тощо) + формант -иця, на підтвердження існування яких свідчать, наприклад, гідроніми: укр. Лука́ва (2 фіксації) - назви рік (бас. Дністра та бас. Дніпра) (Словник гідронімів 329), пол. Łękawa (бас. Вісли й Одеру) (Szulowska i Wolnicz-Pawłowska 166), (похідне) слвц. Lukavec (Závodný 82) і под. Наведені назви водних об’єктів утворені в результаті онімізації відповідних апелятивів на позначення кривизни, вигину (річки, потоку, 
струмка), що й підтверджують: укр. лука́вий 'вигнутий' (Желехівський, і Недільський 1: 415), діал. (прикарп.) лу́кавещь 'вигнутий потік' (Личук 334), пол. łękawa 'те, що має форму лука, кривизни' (Kopertowska 59) і под. Означення Верхня вжите тут у функції протиставлення до нп Нижня Лукавиця (див.: нп Нижня Лукавиця в цьому ж районі; Україна 228).

Городисько - село у Старосамбірському р-ні. Об'єднане з нп Нове́ Мícmo (Україна 227). Одна з перших історичних фіксацій назви поселення (Гродзисько) засвідчена у 1569 р. (цит. за: Кісь 39). Пізніше ойконім згадується у складі антропонімів Paweł Horodyski у 1633 р. (Архив I/6: 668669) та Joannem Horodyski у 1668 р. (Архив I/10: 268); він же - Городисько (Grodzisko), 1785-1788 pp., 1819-1820 pр. (Йосифінська 85); Городисько, 1946 р. (Українська 136). Ойконім кваліфікуємо як дериват від географічного апелятива городисько, пор., наприклад, зХ.-укр. городи́сько 'городище' (Великий 255) городи́ще 'давнє земляне укріплення, городище' (Словарь 1: 315), 'поселення, укріплене валами і ровами' (Словник української мови II: 136), ст.-укр. городищє, городисчє, городишчє, городишъчє, хородищє 'поселення, укріплене валами і ровами, городище; місце, де збереглися рештки укріпленого поселення' (Словник української мови XVI 7: 35-36), рос. діал. городи́ще 'гора, пагорб, підвищення', 'підводна гряда, підводний скелястий гребінь', 'урочище', слвн. gradíšč 'місце, на якому було місто, замок', 'вал, стіна' та ін. (Этимологический 7: 34-35). Пор. ще інослов'янське споріднене нп Hradisko на Сході Словаччини (Пахомова 132).

Демня - село у Миколаївському р-ні. Назва населеного пункту відома з 1453 р. у найменувальній конструкції описового типу (Демня на Зубрі, або Воля) (цит. за: Лаба, «Історія села Демня» 7). Згодом ойконім згадується в 1464 р. (Лаба, «Історія села Демня» 7); у 1466 р. поселення продовжує носити подвійну назву: (Зубри, або Демні) (цит. за: Лаба, «Історія села Демня» 7)궁 у 1469 р. воно фіксується як (Демня) (цит. за: Лаба, «Історія села Демня» 8). До 1473 р., згідно з фактичними даними, засвідченими історичними документами, функціонують обидва офіційні ойконіми: (Демня) і (Зубра) (цит. за: Лаба, «Історія села Демня» 7-8). У XV ст. поселення згадується під назвою Demnia (цит. за: Котович «Походження назв населених пунктів Опілля» 27); у 1546 р. - (Демня, або Воля) (цит. за: Лаба, «Історія села Демня» 8); у 1553 р. - (Демня) (цит. за: Лаба, «Історія села Демня» 9); у 1681 р. - (в селі Демни) (цит. за: Лаба, «Історія села Демня» 64); у 1763 р. - (в Демні) (цит. за: Лаба, «Історія села Демня» 19); у 1785-1788 pp. та 1819-1820 pp. - Демня (Dетпіа) (Йосифінська 98); у 1880 р. - Demnia (Słownik geograficzny I: 956); у 1847 р. - в (Демні) (цит. за: Лаба, «Історія села Демня» 72); у 1882 р. - в (Демни) (цит. за: Лаба, «Історія села Демня» 76); у 1888 р. - в (Демни) (цит. за: Лаба, «Історія села Демня» 95); у 1902 р. - на Демні (цит. за: Устиянович 211); до 1946 р. - Демня

\footnotetext{
1 Зазначимо, що краєзнавець В. П. Лаба вважає, що первісно поселення під назвами Зубра і Демня були одним населеним пунктом. Докладніше про це див.: (Лаба, «Історія села Демня» 7).
} 
(Українська 898); у 1946 р. - Димівка (Українська 142); від 1950 р. - Димівка (цит. за: Лаба, «Історія села Демня» 4); у 1968 р. - Ди́мівка (Історія 471); до поч. 90-х років - Димівка (цит. за: Лаба, «Історія села Демня» 4); у 2007 р. «село Демня над Жуброю» (цит. за: Лаба, «Історія села Демня» 64).

Існує кілька версій пояснення етимології назви с. Демня: 1) відома думка львівського краєзнавця В. П. Лаби, за якою ойконім мотивований тим, що це поселення раніше було постійно задимлене в результаті розвинутого тут залізодобувного виробництва. Докладніше про це в: (Лаба, «Історія села Демня» 5); 2) можливо, припускає також В. П. Лаба, назва села пов'язана зі словом домниця 'піч для виплавки заліза 3 болотяної руди’ (Лаба, «Історія села Демня» 5); 3) на нашу думку, це лексико-семантичне утворення від апелятива демня, на вірогідність чого свідчить, наприклад, укр. де́мня 'димохід (у кузні)' (Желехівський, і Недільський, 1: 176). Щодо компонента Зубра в історичному варіанті, то він відгідронімного походження, пор. місцева р. Зубра (бас. Дністра). До споріднених топонімів додамо ще назву млина Demnia Niżna, 1887 р. у колишньому сусідньому Стрийському повіті (на пд.-зх. від нп Побук) (Słownik geograficzny VIII: 346).

Історичний варіант назви села Воля мотивований відповідним апелятивом укр. во́ля 'відсутність обмежень; привілля', 'звільнення селян від кріпацтва' (Словарь 1: 253; Словник української мови I: 735-736).

Висновки та перспективи досліджень. Таким чином, дослідивши ойконіми Бі́брка, Бі́тля, Бо́риня, Вели́ке Коло́дно, Верхня Лукавиия, Городисько та Демня Львівської області, можна констатувати таке:

1. Місцевий ойконімікон своєрідний своїми лексичними й фонетичними особливостями (на що часто-густо має вплив, найімовірніше, сусідство польськомовного регіону), водночас більшість назв поселень сформувалася на українськомовному грунті.

2. Семантика топонімооснов розглядуваних назв поселень у переважній більшості пов'язана з місцевими топографічними особливостями.

3. Історична топонімія Львівщини - це важливий складник повного історико-етимологічного словника ойконімів України загалом і Львівської області зокрема.

\section{Список використаних джерел}

Архив Юго-Западной России, изд. Временною комиссиею для разбора древних актов [...]. Киев: В университетской типографии, ч. I-VIII, 1859-1914.

Великий тлумачний словник сучасної української мови, укл. і гол. ред. В. Т. Бусел. Київ; Ірпінь: ВТФ «Перун», 2007.

Етимологічний словник літописних географічних назв Південної Русі, відп. ред. О. С. Стрижак. Київ: Наукова думка, 1985.

Етимологічний словник української мови, за ред. О. С. Мельничука. В 7 т. Київ: Наукова думка, 1982-2012.

Желехівський, Євгеній, і Недільський, Софрон. Малорусько-німецький словар. В 2 т. Львів: 3 друкарні товариства імені Шевченка, 1886. 
Історія міст і сіл Украӥнської РСР: Львівська область, ред. колегія: В. Ю. Маланчук (голова), М. Я. Гнидюк, Б. К. Дудикевич та ін. Київ: Головна редакція Української радянської енциклопедії АН УРСР, 1968.

Йосифінська (1785-1788) і Францисканська (1819-1820) метрики. Перші поземельні кадастри Галичини. Покажчик населених пунктів, відп. ред. П. Захарчишина; склали: П. Пироженко, В. Сіверська. Київ: Наукова думка, 1965.

Новгородские писцовые книги, изд. Археографическою комиссиею. В 4 т. Санкт-Петербург:

Сенатская типография, 1859-1915.

Словарь української мови, за ред. Б. Д. Грінченка. В 4 т. Київ, 1907-1909.

Словник гідронімів України, ред. колегія: А. П. Непокупний, О. С. Стрижак, К. К. Цілуйко. Київ: Наукова думка, 1979.

Словник староукраїнської мови XIV-XV cm., ред. Л. Л. Гумецька, I. М. Керницький. У 2 т. Київ: Наукова думка, 1977-1978.

Словник української мови, за ред. І. К. Білодіда. В 11 т. Київ: Наукова думка, 1970-1980.

Словник української мови XVI - перша половина XVII ст., відп. ред. Д. Гринчишин. У 17 т. Львів: Інститут українознавства імені І. Крип'якевича НАН України, 1994-2017.

Слоўнік беларускіх гаворак паўночна-заходняй Беларусі $i$ яе пагранічча, рэд. Ю. Ф. Мацкевіч. У 5 т. Мінск: Навука і тэхніка, 1979-1986.

Україна: Адміністративно-територіальний устрій (станом на 1 січня 2012 року), відп. ред. Г. П. Скопненко; упоряд. $\quad$ В. І. Гапотченко. Київ: Парламентське видавництво, 2012.

Українська РСР: Адміністративно-територіальний поділ на 1 вересня 1946 р., відп. ред. М. Ф. Попівський. Київ: Українське видавництво політичної літератури, 1947.

Этимологический словарь славянских языков: Праславянский лексический фонд, под ред. О. Н. Трубачева, А. Ф. Журавлева, Ж. Ж. Варбот. В 41 т. Москва: Наука, 1974-2018. Hydronimia Wisły. Cz. 1: Wykaz nazw w układzie hydrograficznym, pod red. P. Zwolińskiego. Wroclaw etc.: Wydawnictwo PAN, 1965.

Nazwy geograficzne Śląska. pod red. S. Rosponda. W 4 t. Warszawa etc.: Wydawnictwo PAN, 1970-1988.

Russisches geographisches Namenbuch, Begr. von M. Vasmer. Bd I-X. Wiesbaden: Akademie der Wissenschaften und der Literatur, 1962-1980.

Słownik geograficzny Królestwa Polskiego i innych krajów słowiańskich, pod red. F. Sulimierskiego. W 15 t. Warszawa: Nowy Świat, 1880-1902.

Słownik prasłowiański, pod red. F. Sławskiego. W 8 t. Wrocław etc.: Wydawnictwo PAN, 19742001.

Szulowska, Wanda i Wolnicz-Pawłowska, Ewa. Nazwy wód w Polsce. W 2 cz. Cz. 1. Warszawa: Wydawnictwo Naukowe Semper, 2001.

\section{Sources}

Arkhyv Yuho-Zapadnoi Rossyy, yzd. Vremennoiu komyssyeiu dlia razbora drevnykh aktov [...]. Kyev: V unyversytetskoi typohrafyy, ch. I-VIII, 1859-1914.

Velykyi tlumachnyi slovnyk suchasnoi ukrainskoi movy, edited by V. T. Busel. Kyiv; Irpin: VTF "Perun", 2007.

Etymolohichnyi slovnyk litopysnykh heohrafichnykh nazv Pivdennoi Rusi, edited by O. S. Stryzhak. Kyiv: Naukova dumka, 1985.

Etymolohichnyi slovnyk ukrainskoi movy, edited by O.S. Melnychuk. 7 vols. Kyiv: Naukova dumka, 1982-2012.

Zhelekhivskyi, Yevhenii, Nedilskyi, Sofron. Malorusko-nimetskyi slovar. 2 vols. Lviv: Z drukarni tovarystva imeni Shevchenka, 1886.

Istoriia mist i sil Ukrainskoi RSR: Lvivska oblast, edited by V. Yu. Malanchuk. Kyiv: Holovna redaktsiia Ukrainskoi radianskoi entsyklopedii AN URSR, 1968. 
Yosyfinska (1785-1788) i Frantsyskanska (1819-1820) metryky. Pershi pozemelni kadastry Halychyny. Pokazhchyk naselenykh punktiv, edited by P. Zakharchyshyna. Kyiv: Naukova dumka, 1965.

Novgorodskie piscovye knigi, izd. Arheograficheskoju komissieju. Sankt-Peterburh: Senatskaia typohrafyia, 6 vols, 1859-1915.

Slovar ukrainskoi movy, edited by B. D. Hrinchenko. 4 vols. Kyiv, 1907-1909.

Slovnyk hidronimiv Ukrainy, edited by A. P. Nepokupnyi, O. S. Stryzhak, K. K. Tsiluiko. Kyiv: Naukova dumka, 1979.

Slovnyk staroukrainskoi movy XIV-XV st., edited by L. L. Humetska, I. M. Kernytskyi. 2 vols. Kyiv: Naukova dumka, 1977-1978.

Slovnyk ukrainskoi movy, edited by I. K. Bilodid. 11 vols. Kyiv: Naukova dumka, 1970-1980.

Slovnyk ukrainskoi movy XVI - persha polovyna XVII st., edited by D. Hrynchyshyn. 17 vols. Lviv, 1994-2017.

Sloy̆nik belaruskikh havorak pay̆nochna-zakhodniai Belarusi i yae pahranichcha, edited by Yu. F. Matskevich. 5 vols. Minsk: Navuka i tэkhnika, 1979-1986.

Ukraina: Administratyvno-terytorialnyi ustrii (stanom na 1 sichnia 2012 roky), edited by

H. P. Skopnenko. Kyiv: Parlamentske vydavnytstvo, 2012.

Ukrainska RSR: Administratyvno-terytorialnyi podil na 1 veresnia 1946 roky, edited by

M. F. Popivskyi. Kyiv: Ukrainske vydavnytstvo politychnoi literatury, 1947.

Jetimologicheskij slovar' slavjanskih jazykov: Praslavjanskij leksicheskij fond, edited by O. N. Trubacheva. 41 vol. Moskva: Nauka, 1974-2018.

Hydronimia Wisły. Cz. 1: Wykaz nazw w układzie hydrograficznym, pod red. P. Zwolińskiego. Wroclaw etc.: Wydawnictwo PAN, 1965.

Nazwy geograficzne Śląska. pod red. S. Rosponda. W 4 t. Warszawa etc.: Wydawnictwo PAN, 1970-1988.

Russisches geographisches Namenbuch, Begr. von M. Vasmer. Bd I-X. Wiesbaden: Akademie der Wissenschaften und der Literatur, 1962-1980.

Słownik geograficzny Królestwa Polskiego i innych krajów słowiańskich, pod red. F. Sulimierskiego. W 15 t. Warszawa: Nowy Świat, 1880-1902.

Słownik prasłowiański, pod red. F. Sławskiego. W 8 t. Wrocław etc.: Wydawnictwo PAN, 19742001.

Szulowska, Wanda i Wolnicz-Pawłowska, Ewa. Nazwy wód w Polsce. W 2 cz. Cz. 1.Warszawa: Wydawnictwo Naukowe Semper, 2001.

\section{Список використаної літератури}

Бучко, Дмитро. Походження назв населених пунктів Покуття. Львів: Світ, 1990.

Бучко, Дмитро, Бучко, Микола. «Надсяння: Назви найдавніших поселень». Наш край Любачівщина, вип. 1, 2000, с. 6-16.

Вербич, Святослав. Гідронімія басейну Дністра. Луцьк: Видавництво «Терен», 2017.

Грабовецький, Володимир. Звенигород. Львів, 1959.

Грабовецький, Володимир, і Гопало, Іван. Городок: історико-краєзнавчий нарис. Львів: Каменяр, 1968.

Демчук, Марія. «Найдавніші українські ойконіми відантропонімного походження: питання етимології». Народознавчі зошити, № 1, 2018, с. 150-156. https://doi.org/10.15407/nz2018.01.150

Долинська, Мар'яна. «Історична топографія самоврядних передмість міста Львова XVIXVIII ст.». Дрогобицький краєзнавчий збірник, вип. 9, 2005, с. 214-224.

Кісь, Ярослав. «Виникнення і розташування міст на території Руського і Белзького воєводств від XIV до середини XVII століть». Архіви України, № 1, 1968, с. 35-41.

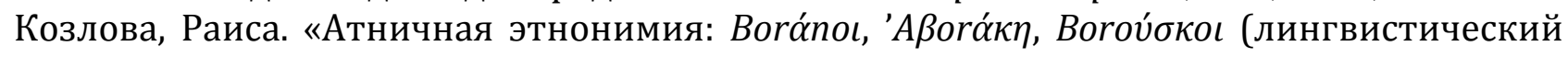
кемментарий)». Студії з ономастики та етимології. 2014, 2014, с. 26-45. 
Котович, Віра. Походження назв населених пунктів Опілля. Дрогобич: Відродження, 2000.

Котович, Віра. Походження назв населених пунктів Перемишлянщини. Дрогобич: Вимір, 2006.

Купчинський, Олег. Студії з історії української мови та ойконімї̈: вибрані статті та матеріали. У 3 т. Т. 1. Львів: Дослідно-видавничий центр Наукового товариства імені Шевченка, 2011.

Лаба, Василь. «Слідами зниклих сіл: Зниклі села на території району». Радянський шлях, 7 жовтня, 1989.

Лаба, Василь. Історія села Баківці від найдавніших часів до 1939 року. Львів, 1996.

Лаба, Василь. Історія села Бориничі від найдавніших часів до 1939 року. Львів, 1996.

Лаба, Василь. Історія села Жирівка: від найдавніших часів до 1939 року. Львів, 2002.

Лаба, Василь. Історія села Ліщин від найдавніших часів до 1939 року. Львів, 2005.

Лаба, Василь. Історія села Демня від найдавніших часів до 1939 року. 2 вид., доп. Львів, 2007.

Личук, Світлана. Семантика та структура народних географічних назв ІваноФранківщини. Дис. ... канд. філол. наук: 10.02.01. Івано-Франківсь, 2015.

Лучик, Василь. Етимологічний словник топонімів Украӥни. Київ: Видавничий центр «Академія», 2014.

Масенко, Лариса. Гідронімія Східного Поділля. Київ: Наукова думка, 1979.

Пахомова, Світлана. «Асиміляція українських назв населених пунктів у Східній Словаччині». Студії з ономастики та етимології. 2017-2018, 2018, с. 130-139.

Подорожі в Украӥнські Карпати: збірник, упор. і вступ. ст. М. А. Вальо. Львів: Каменяр, 1993.

Редьква, Ярослав. «Реконструкція ойконімійної системи Львівської землі Руського воєводства кінця XIV ст.». Студії з ономастики та етимології. 2005, 2005, с. 153170.

Редьква, Ярослав. «Польськомовна фонетична адаптація й транслітерація приголосних звуків в ойконімії Галицької та Львівської земель колишнього Руського воєводства». Студії з ономастики та етимології. 2008, 2008, с. 145-170.

Рудницький, Ярослав. Географічні назви Бойківщини. 2-ге вид. Вінніпег: Накладом Української вільної академії наук, 1962.

Свєшніков, Ігор. Звенигород. Львів, 1987.

Устиянович, Корнило. «Путь за Бескид: «Святославіє» і традиція о Святославі 1015 р.». Подорожі в Украӥнські Карпати, упор. і вступ. ст. М. А. Вальо. Львів: Каменяр, 1993, с. 199-219.

Худаш, Михайло, і Демчук Марія. Походження украӥнських карпатських $i$ прикарпатських назв населених пунктів (відантропонімні утворення). Київ: Наукова думка, 1991.

Худаш, Михайло. Украӥнські карпатські і прикарпатські назви населених пунктів: Утворення від слов'янських автохтонних відкомпозитних скорочених особових власних імен. Київ: Наукова думка, 1995.

Худаш, Михайло. Українські карпатські і прикарпатські назви населених пунктів (утворення від відапелятивних антропонімів). Львів: Видавнича фірма «Афіша», 2004.

Худаш, Михайло. Українські карпатські і прикарпатські назви населених пунктів (відапелятивні утворення). Львів: Видавнича фірма «Афіша», 2006.

Черняхівська, Євгенія. Топонімія Львівщини. Дис. ... канд. філол. наук: 10.02.01. Львів, 1966. 
Шульгач, Віктор. «Основа *but- в гідронімії України». Ономастика України першого тисячоліття нашої ери, відп. ред. І. М. Желєзняк. Київ: Наукова думка, 1992, c. 87-94.

Шульгач, Виктор. «К реконструкции праславянского лексического фонда: производные на *-упь (на основе ономастического материала «Новгородских писцовых книг»)». Студії з ономастики та етимології. 2003, 2003, с. 69-89.

Czapla, Anna. Nazwy miejscowości historycznej ziemi Lwowskiej. Lublin: Towarzystwo Naukowe Katolickiego Uniwersytetu Lubelskiego Jana Pawła II, 2011.

Kopertowska, Danuta. "Nazwy geograficzne Radomskiego". Onomastica, r. XXXIX, 1994, s. 4978.

Kuropatnicki, Ewaryst. Geografia albo dokładne opisanie królestw Galicyi i Łodomeri. wydanie powtórne. Lwów: W drukarni zakładu narodowego imienia Ossolińskich, 1858 (reprint: wyd. Roksana oraz Muzeum Okręgowe w Krośnie. Krosno, 1998).

Rudnicki, Jarosław. Nazwy geograficzne Bojkowszczyzny. Lwów: Publisher: Kasa im. Rektora J. Mianowskiego Instytut Popierania Polskiej Twórczości Naukowej, 1939.

Závodný, Andrej. "Zopár novších poznámok k výkladom niektorých hydroným z povodia slovenských prítokov Moravy". Студї з ономастики та етимологіï. 2011-2012, 2012, c. 79-91.

\section{References}

Buchko, Dmytro. Pokhodzhennia nazv naselenykh punktiv Pokuttia. Lviv: Svit, 1990.

Buchko, Dmytro, Buchko, Mykola. "Nadsiannia: Nazvy naidavnishykh poselen". Nash krai Liubachivshchyna, iss. 1, 2000, pp. 6-16.

Verbych, Sviatoslav. Hidronimiia baseinu Dnistra. Lutsk: Vydavnytstvo “Teren”, 2017.

Hrabovetskyi, Volodymyr. Zvenyhorod. Lviv, 1959.

Hrabovetskyi, Volodymyr, Hopalo, Ivan. Horodok: istoryko-kraieznavchyi narys. Lviv: Kameniar, 1968.

Demchuk, Maria. "The most ancient ukrainian oikonims of anthroponymic origin: the question of etymology". The Ethnology Notebooks, no. 1, 2018, pp.150-156. https://doi.org/10.15407/nz2018.01.150

Dolyns'ka, Mariana. "Historical topography of self-managing suburbs of the city of L'viv of the $16^{\text {th }}-18^{\text {th }}$ cc.". Drohobych Regional Studies, iss. 9, Drohobych: Kolo, 2005, pp. 214224.

Kis, Yaroslav. "Vynyknennia i roztashuvannia mist na terytorii Ruskoho i Belzkoho voievodstv vid XIV do seredyny XVII stolit". Arkhivy Ukrainy, № 1, 1968, pp. 35-41.

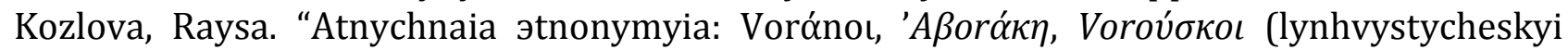
kemmentaryi)". Studii z onomastyky ta etymolohii. 2014, 2014, pp. 26-45.

Kotovych, Vira. Pokhodzhennia nazv naselenykh punktiv Opillia. Drohobych: Vidrodzhennia, 2000.

Kotovych, Vira. Pokhodzhennia nazv naselenykh punktiv Peremyshlianshchyny. Drohobych: Vymir, 2006.

Kupchynskyi, Oleh. Studii z istorii ukrainskoi movy ta oikonimii: vybrani statti ta materialy. 3 vols. Vol. 1. Lviv: Doslidno-vydavnychyi tsentr Naukovoho tovarystva imeni Shevchenka, 2011.

Laba, Vasyl. "Slidamy znyklykh sil: Znykli sela na terytorii raionu”. Radianskyi shliakh, 7 Mar., 1989.

Laba, Vasyl. Istoriia sela Bakivtsi vid naidavnishykh chasiv do 1939 roku. Lviv, 1996.

Laba, Vasyl. Istoriia sela Borynychi vid naidavnishykh chasiv do 1939 roku. Lviv, 1996.

Laba, Vasyl. Istoriia sela Zhyrivka: vid naidavnishykh chasiv do 1939 roku. Lviv, 2002.

Laba, Vasyl. Istoriia sela Lishchyn vid naidavnishykh chasiv do 1939 roku. Lviv, 2005.

Laba, Vasyl. Istoriia sela Demnia vid naidavnishykh chasiv do 1939 roku. $2^{\text {nd }}$ ed. Lviv, 2007. 
Lychuk, Svitlana. Semantyka ta struktura narodnykh heohrafichnykh nazv IvanoFrankivshchyny. PhD Thesis. Ivano-Frankivsk, 2015.

Luchyk, Vasyl. Etymolohichnyi slovnyk toponimiv Ukrainy. Kyiv: Vydavnychyi tsentr "Akademiia", 2014.

Masenko, Larysa. Hidronimiia Skhidnoho Podillia. Kyiv: Naukova dumka, 1979.

Pakhomova, Svitlana. "Asymiliatsiia ukrainskykh nazv naselenykh punktiv u Skhidnii Slovachchyni”. Studii z onomastyky ta etymolohii. 2017-2018, 2018, pp. 130-139.

Podorozhi v Ukrainski Karpaty, edited by M. A. Valo. Lviv: Kameniar, 1993.

Redkva, Yaroslav. "Rekonstruktsiia oikonimiinoi systemy Lvivskoi zemli Ruskoho voievodstva kintsia XIV st.”. Studii z onomastyky ta etymolohii. 2005, 2005, pp. 153-170.

Redkva, Yaroslav. "Polskomovna fonetychna adaptatsiia y transliteratsiia pryholosnykh zvukiv v oikonimii Halytskoi ta Lvivskoi zemel kolyshnoho Ruskoho voievodstva". Studii z onomastyky ta etymolohii. 2008, 2008, pp. 145-170.

Rudnytskyi, Yaroslav. Heohrafichni nazvy Boikivshchyny. 2nd ed. Vinnipeg, 1962.

Svieshnikov, Ihor. Zvenyhorod. Lviv, 1987.

Ustyianovych, Kornylo. "Put za Beskyd: "Sviatoslaviie" i tradytsiia o Sviatoslavi 1015 r.". Podorozhi v Ukrainski Karpaty, edited by M. A. Valo. Lviv: Kameniar, 1993, pp. 199219.

Khudash, Mykhailo, and Demchuk Mariia. Pokhodzhennia ukrainskykh karpatskykh $i$ prykarpatskykh nazv naselenykh punktiv (vidantroponimni utvorennia). Kyiv: Naukova dumka, 1991.

Khudash, Mykhailo. Ukrainski karpatski i prykarpatski nazvy naselenykh punktiv: Utvorennia vid slovianskykh avtokhtonnykh vidkompozytnykh skorochenykh osobovykh vlasnykh imen. Kyiv: Naukova dumka, 1995.

Khudash, Mykhailo. Ukrainski karpatski i prykarpatski nazvy naselenykh punktiv (utvorennia vid vidapeliatyvnykh antroponimiv). Lviv: Vydavnycha firma "Afisha", 2004.

Khudash, Mykhailo. Thus, based on the materials of documented historical fixations of one of the oldest oikonyms of the studied region, both the features of word-formation models and phonetic modifications of the analyzed onyms in time were traced. Lviv: Vydavnycha firma "Afisha", 2006.

Cherniakhivska, Yevheniia. Toponimiia Lvivshchyny. PhD Thesis Abstract. Lviv, 1966.

Shulhach, Viktor. "Osnova *but- v hidronimii Ukrainy". Onomastyka Ukrainy pershoho tysiacholittia nashoi ery, edited by I. M. Zheliezniak. Kyiv: Naukova dumka, 1992, pp. 87-94.

Shulhach, Vyktor. "K rekonstruktsyy praslavianskoho leksycheskoho fonda: proyzvodnye na *-yn (na osnove onomastycheskoho materyala "Novhorodskykh pystsovykh knyh")". Studii z onomastyky ta etymolohii. 2003, 2003, pp. 69-89.

Czapla, Anna. Nazwy miejscowości historycznej ziemi Lwowskiej. Lublin: Towarzystwo Naukowe Katolickiego Uniwersytetu Lubelskiego Jana Pawła II, 2011.

Kopertowska, Danuta. "Nazwy geograficzne Radomskiego". Onomastica, r. XXXIX, 1994, pp. 49-78.

Kuropatnicki, Ewaryst. Geografia albo dokładne opisanie królestw Galicyi i Łodomeri. wydanie powtórne. Lwów: W drukarni zakładu narodowego imienia Ossolińskich, 1858 (reprint: wyd. Roksana oraz Muzeum Okręgowe w Krośnie. Krosno, 1998).

Rudnicki, Jarosław. Nazwy geograficzne Bojkowszczyzny. Lwów: Publisher: Kasa im. Rektora J. Mianowskiego Instytut Popierania Polskiej Twórczości Naukowej, 1939.

Závodný, Andrej. "Zopár novších poznámok k výkladom niektorých hydroným z povodia slovenských prítokov Moravy". Studii z onomastyky ta etymolohii. 2011-2012, 2012, pp. 79-91. 